\title{
Distribution, population assessment and conservation of the endemic Bermuda killifishes Fundulus bermudae and Fundulus relictus
}

\author{
Mark E. Outerbridge ${ }^{1, *}$, John Davenport ${ }^{2}$, Anne F. Glasspool ${ }^{1}$ \\ ${ }^{1}$ Bermuda Biodiversity Project, Bermuda Zoological Society, PO Box FL 145, Flatts, FL BX, Bermuda \\ ${ }^{2}$ Department of Zoology, Ecology \& Plant Science, University College Cork, Distillery Fields, North Mall, Cork, Ireland
}

\begin{abstract}
Fundulus bermudae and Fundulus relictus are endemic to Bermuda and are protected under the Bermuda Protected Species Act 2003. These killifishes were described as abundant and widespread in the wetland communities of Bermuda during the late 19th and early 20th centuries. Surveys were undertaken during 2004-2005 to determine the current distribution, as well as to estimate the size and structure of each Fundulus population. Killifishes are now found in only 9 isolated ponds. For 6 ponds, populations appear to be large enough to be self-sustaining for the foreseeable future; for 1 pond, the population is low enough to be regarded as vulnerable. Estimates were not feasible in the case of the remaining 2 ponds.
\end{abstract}

KEY WORDS: Anchialine ponds · Bermuda - Fundulus bermudae · Fundulus relictus · Killifishes . Mark and recapture · Visible implant elastomer

\section{INTRODUCTION}

Bermuda $\left(32^{\circ} 18^{\prime} \mathrm{N}, 64^{\circ} 46^{\prime} \mathrm{W}\right)$ consists of over 120 islands, with a total land area of $55 \mathrm{~km}^{2}, 960 \mathrm{~km}$ from the USA coast. It lies on top of a volcanic seamount that rises $4000 \mathrm{~m}$ from the seafloor, capped by limestone and coral reefs. All islands are concentrated along the southern edge of the seamount, the larger ones forming a narrow chain linked by causeways and bridges. Bermuda has no permanent surface freshwater streams or lakes and fewer than 20 anchialine ponds scattered across the islands (Thomas \& Logan 1992). These ponds (3 of which are man-made) are isolated, saline, land-locked bodies of water with permanent subterranean connections to the ocean. Natural freshwater ponds are few, and mostly man-made. Widespread drainage of freshwater marshes was employed as part of mosquito control methods in the first half of the 20th century, as the government attempted to prevent the spread of mosquito-borne diseases. In the 1930s, wetlands were used for the disposal of garbage, and after the 1950s this activity became the main feature of marsh reclamation. During this period, large tracts of marshland and numerous ponds were completely filled, leading to major losses in biodiversity. In contrast, the total acreage of saline ponds has remained unchanged since the end of the 19th century (Sterrer \& Wingate 1981) and may function as refugia for endemic species. Thomas et al. (1991, 1992) reported detailed descriptions of the physical and biotic characteristics of the 6 largest anchialine ponds in Bermuda. Most of the ponds in Bermuda (irrespective of salinity) are small and shallow with low habitat complexity.

To date, 433 species of fishes have been recorded in Bermuda, of which 8 are currently recognized as endemic (Smith-Vaniz et al. 1999). Two of these 8 endemics belong to the killifish genus Fundulus: F. bermudae Günther 1874 and F. relictus Able \& Felley 1988. These are believed to be descendants of the 
F. heteroclitus-F. grandis species group, and to have originated from populations on the east coast of the USA (Able \& Felley 1988) at least 5000 yr before present (Smith-Vaniz et al. 1999, Grady et al. 2001). Uni- and multivariate analyses of adult morphology and isozyme analysis of natural populations indicate that both of the Bermuda forms are endemic and distinct from F. heteroclitus (Able \& Felley 1988). The overall shape of both species is typical for the $F$. heteroclitus-F. grandis group. Both sexes have a deep vertical body profile, a rather short and robust body with posteriorly placed dorsal and anal fins of approximately equal size, a deep caudal peduncle, and a somewhat rounded caudal fin (Fig. 1). Bermuda's fundulids are sexually dimorphic: females are uniform olive to brown in colour, darker above, lighter below, without definite markings; males are darker in colour, usually dark green or olive with a yellowish underside, and when spawning have a dark spot towards the rear of the dorsal fin. F. bermudae and F. relictus are, however, indistinguishable in the field, though it appears that no pond contains mixed populations (Table 1). For more detailed physical descriptions see Able \& Felley (1988).

Fundulus bermudae and F. relictus are benthopelagic in the pond habitat, appear to form loose schools made up of equally sized individuals, and are omnivorous opportunistic feeders. Stomach content analysis has revealed that $F$. bermudae inhabiting Mangrove Lake, the largest pond in Bermuda, eats filamentous green algae and plant material, molluscs, crustaceans and insects (Rand 1981).

The annual spawning cycle for Fundulus bermudae is near-synchronous for both sexes. The spawning season for males and females begins in February, reaches a peak in May and June, respectively, and falls abruptly after June until September; the end of the spawning season (Outerbridge et al. 2007). Laboratory observations of spawning site preferences for $F$. bermudae and $F$. relictus suggest that both species may deposit eggs in algal mats or submerged vegetation (Able \& Hata 1984). Such solid surfaces may include the roots and pneumatophores of the red and black mangrove tree Rhizophora mangle and Avicennia nitida, as well as widgeon grass Ruppia maritima, all of which are very common in many of the Fundulus ponds in Bermuda. The lifespan of Bermuda's killifishes is unknown; however, individuals have been kept in captivity at the Bermuda Aquarium, Natural History Museum and Zoo for 5 yr (J. Gray pers. comm.)

In 2003, Fundulus bermudae and F. relictus were listed as protected under the Bermuda Protected Species Act (www.bermudalaws.bm). Additionally, there are plans to submit an application for both species to be included on the IUCN (The World Conservation Union) Red List of Threatened Species. There have been few opportunities for these fishes to increase their range, largely due to the restriction in habitat availability and the fragmentation of the wetlands in Bermuda. Additionally, quantitative assessments of each pond population have been lacking and are limiting conservation efforts.

The aims of the present study were (1) to determine the current distribution of Bermuda's killifishes, (2) to estimate the size of each extant population, and (3) to describe the basic structure of these populations.

\section{MATERIALS AND METHODS}

A field list of 44 potential killifish habitats was drafted, including salt marshes, peat marshes, drainage canals, inland freshwater, brackish and fully marine ponds, mangrove communities, and sheltered,
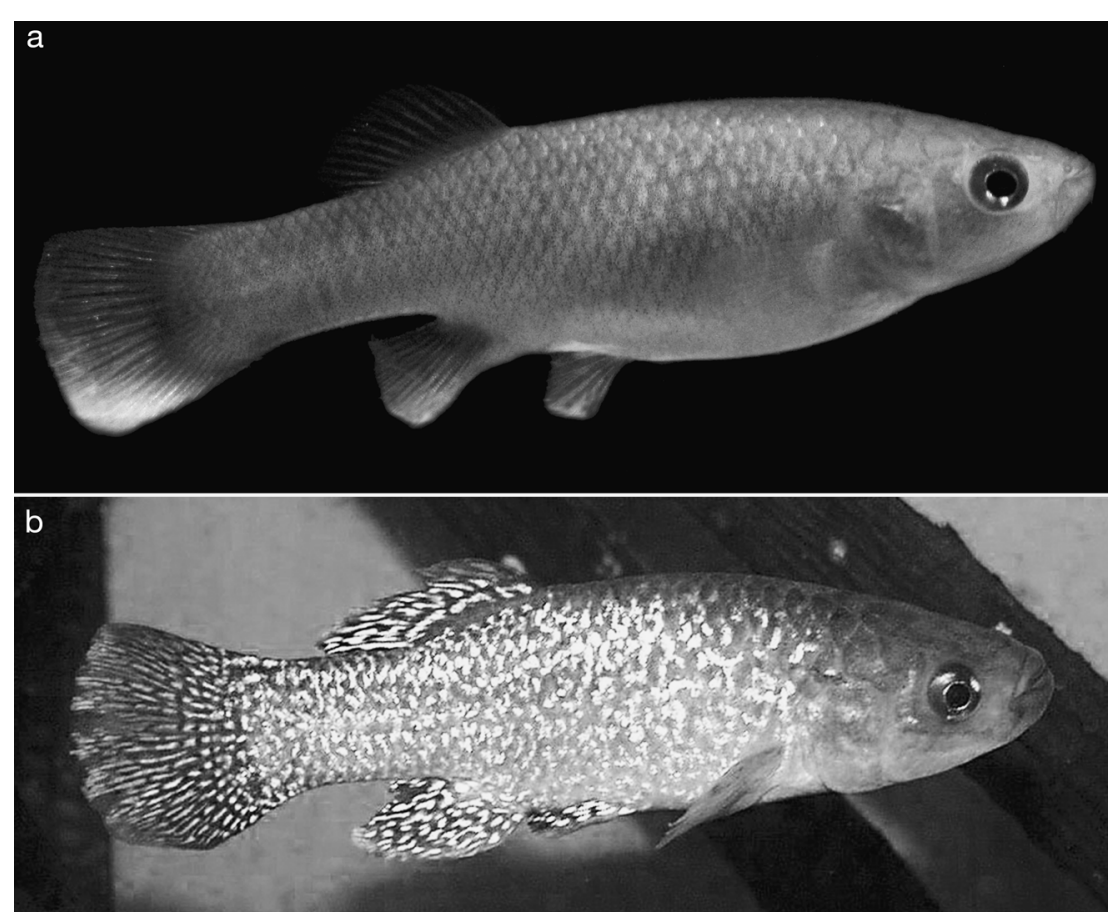

Fig. 1. Fundulus bermudae. (a) Mature female from Trott's Pond and (b) male from Mangrove Lake. Photos: Mark Outerbridge (a) and Jennifer Gray (b) 
Table 1. Fundulus bermudae and F. relictus. Summary of killifish distribution and transfer history among the ponds of Bermuda. na: not applicable

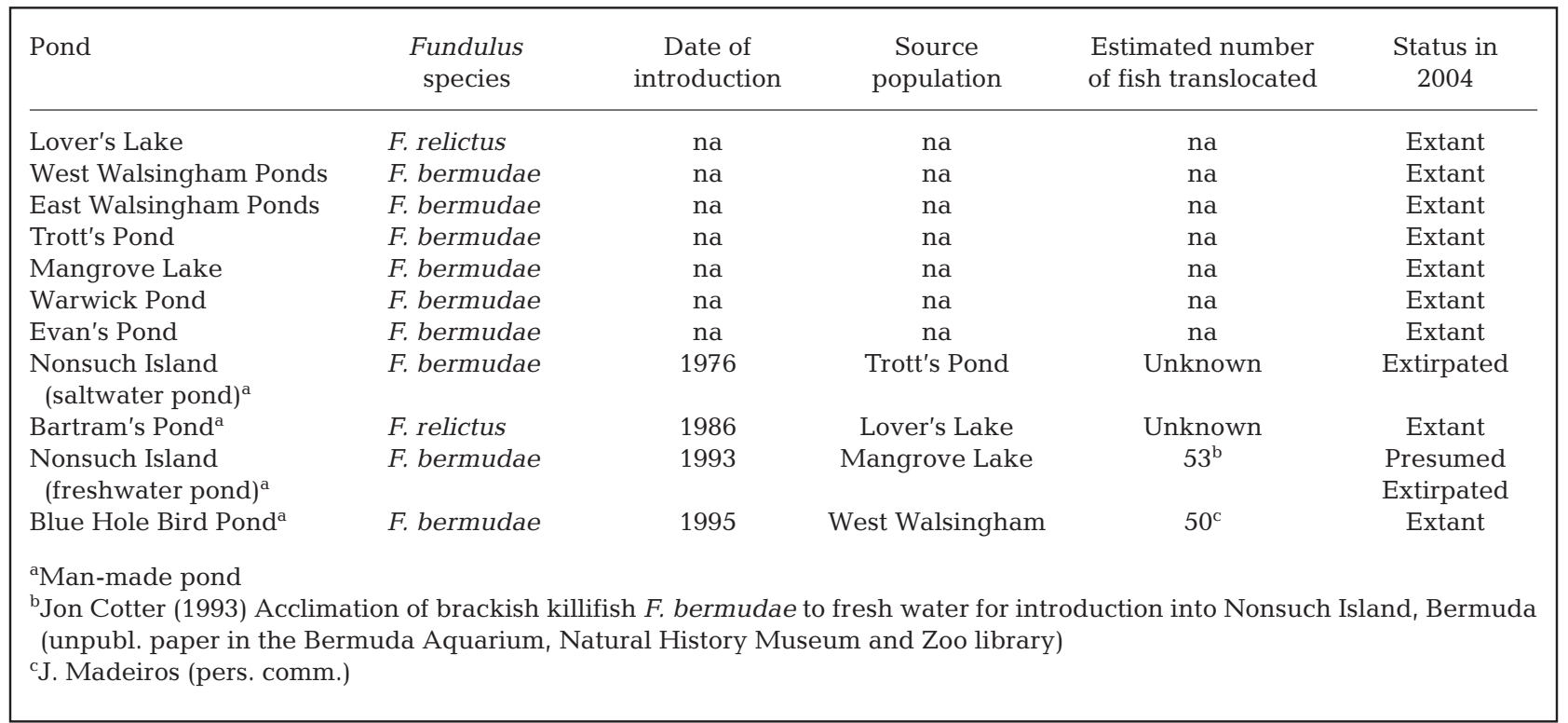

shallow bays dominated by seagrass beds in areas immediately adjacent to coastal mangroves (Outerbridge et al. 2006). Surveying used a combination of direct observation and baited traps.

Minnow traps made of $8 \mathrm{~mm}$ diagonal wire mesh were used. Each measured $425 \mathrm{~mm}$ long and $228 \mathrm{~mm}$ wide with a $165 \mathrm{~mm}$ long conical entrance at both ends that tapered to a $28 \mathrm{~mm}$ diameter opening through which fish could enter the trap. Each trap was baited with a small amount of canned sardines, securely fastened, deployed from a canoe and left to soak for $1 \mathrm{~h}$ at a random location within each habitat. Such traps have been standard materials in numerous investigations of Fundulus species in North America (Kneib \& Stiven 1978, Meredith \& Lotrich 1979, Sweeney et al. 1998, Kneib \& Craig 2001). Kneib \& Craig (2001) evaluated the efficacy of these traps for measuring relative abundance and density of killifishes and suggested that reliable estimates can be made if the traps are used in isolated pools where habitat complexity is low and killifish density remains constant during the sampling period - conditions satisfied in the present study.

Wherever extant populations were found, up to 12 traps were placed at random locations throughout each pond (12 in Mangrove Lake, Trott's Pond, Bartram's Pond and the West Walsingham Ponds; 7 in Warwick Pond; 4 in Lover's Lake; and 3 in the Blue Hole Bird Pond). Population censuses were subsequently performed based on the Petersen Index methodology of mark and recapture (Ricker 1958) using a visible implant elastomer (VIE) (Northwest Marine Technology). VIE effectiveness has been documented by
Dewey \& Zigler (1996), Frederick (1997) and Kneib \& Craig (2001). The pale area on the abdomen adjacent to the proximal base of the pelvic fins was chosen as the tagging site. Application of elastomer to fish was accomplished by full anaesthesia (FINQUEL MS-222 Argent Chemical Laboratories) and injection immediately below the dermis so that the needle tip could still be clearly seen. Immediately after tagging, fish were transferred to a bucket of continuously aerated, untreated pond water and given $2 \mathrm{~h}$ to recover before being released at random locations within each pond.

Sex and total length, measured to the nearest $1 \mathrm{~mm}$, of all killifishes captured were determined at the time of tagging. Whenever possible, sex was recorded based on presence or absence of a dorsal fin ocellus and an anal-sheath on the anal fin, as well as overall body colouration. Males were positively identified when they possessed the dark ocellus on the posterior half of the dorsal fin; females were positively identified if they possessed an anal sheath on the anal fin. Body colouration was used as a secondary identification technique.

Second, third and fourth recapture censuses were performed on each extant population based on the original marking event 1, 2 and $3 \mathrm{wk}$, respectively, after the initial tagging event. All trapped fish were examined for tags and the numbers recorded. Petersen population estimates-calculated as $N=\left[\left(n_{1}+1\right)\right.$ $\left.\left(n_{2}+1\right) /\left(m_{2}+1\right)\right]-1$, where $N=$ the total estimated population, $n_{1}=$ number of fish marked in first sample, $n_{2}=$ total number of fish in the second sample, $m_{2}=$ 
number of marked fish in the second sample-were averaged from the 3 separate recapture events to obtain a mean population size for each pond.

\section{RESULTS}

The 2004-2005 surveys confirmed the existence of populations in the following 9 locations only: Lover's Lake, Bartram's Pond, Mangrove Lake, Trott's Pond, Blue Hole Pond, both East and West Walsingham Ponds, Warwick Pond and Evan's Pond (Fig. 2). No other Fundulus populations were discovered in any of the peripheral wetland communities of Bermuda, including those described as having them at some time in the past $150 \mathrm{yr}$.

Petersen estimates (Table 2), mean lengths, size ranges (Table 3 ), and sex ratio data (Table 4) were collected for all ponds where extant Fundulus populations were found, except for the East Walsingham Ponds and Evan's Pond; no fish could be trapped for marking in these 2 ponds during the survey period. The population estimates (in order of decreasing size) were Mangrove Lake $(11325 ;$ F. bermudae), Trott's Pond $(7926 ;$ F. bermudae), Lover's Lake $(8508 ;$ F. relictus), Blue Hole Bird Pond (5394; F. bermudae), West Walsingham Ponds (2202; F. bermudae), Bartram's Pond $(1793 ;$ F. relictus) and Warwick Pond (436; F. bermudae). Non-parametric Mood Median tests performed on all data sets were used to determine if a significant difference occurred between male and female median sizes (Table 5). Statistically significant differences were found only in Lover's

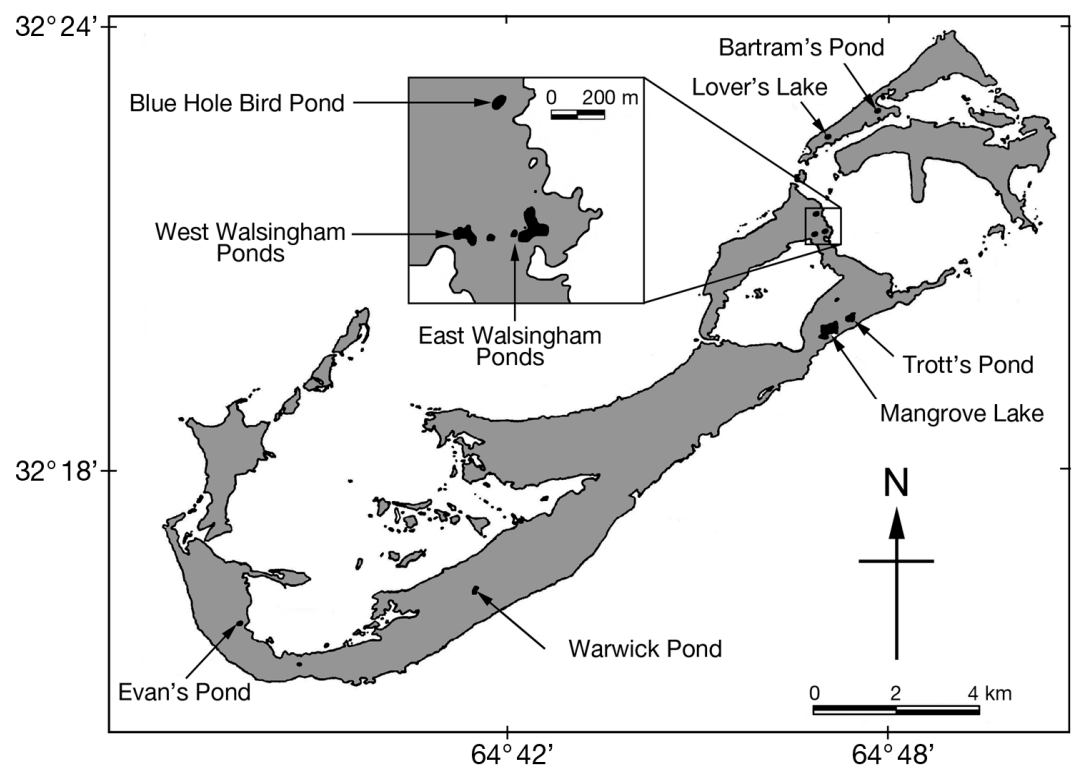

Fig. 2. Fundulus bermudae and F. relictus. Distribution of killifishes in ponds across the islands of Bermuda in 2004 and 2005
Table 2. Fundulus bermudae and F. relictus. Petersen estimates of population (mean $\pm \mathrm{SE}$, ind. pond $^{-1}$ ) for killifish in each of the ponds studied.

\begin{tabular}{|lc|}
\hline Pond & Petersen estimate \\
\hline F. bermudae & \\
Blue Hole Bird Pond & $5394 \pm 480$ \\
Mangrove Lake & $11325 \pm 1884$ \\
West Walsingham Ponds & $2202 \pm 178$ \\
Trott's Pond & $7926 \pm 1576$ \\
Warwick Pond & $436 \pm 13$ \\
F. relictus & \\
Bartram's Pond & $1793 \pm 224$ \\
Lover's Lake & $8508 \pm 1347$ \\
\hline
\end{tabular}

Lake $(\mathrm{p}=0.006)$, the West Walsingham Ponds $(\mathrm{p}=$ $0.023)$, and Warwick Pond $(p=0.009)$. In all 3 populations females were significantly larger than males. Additionally, females outnumbered males in all ponds surveyed, except Trott's Pond, where the sexes occurred in equal numbers. However, chi-square tests performed on the sex ratio data sets for Mangrove Lake, Lover's Lake, Trott's Pond, and Warwick Pond did not show statistically significant differences between female and male numbers $(p>0.05$ in all cases), whereas significant differences were noted in the Blue Hole Bird Pond, Bartram's Pond, and the West Walsingham Ponds populations $(\mathrm{p}<0.001$ in all cases) (Table 5).

\section{DISCUSSION}

\section{Distribution}

The present Bermudian distribution of killifishes is very restricted. In the 19th century, killifishes were abundant and widely distributed throughout the marshes and ponds of Bermuda (Hurdis 1897, Smith-Vaniz et al. 1999). Beebe \& Tee-Van (1933) described killifishes (referred to as the 'mangrove minnow' or 'mangrove mullet') as 'abundant in brackish pools and ponds.' Historical collections also indicate that killifishes were once extant in Stocks Point on St. David's Island, in Pembroke Marsh, and in what was once an area known as Paget East swamp.

During the 1990s local conservationists were aware of extant populations only in Lover's Lake, Mangrove Lake, Trott's Pond, both East and West Walsingham Ponds, Warwick Pond and 
Table 3. Fundulus bermudae and F. relictus. Mean, median and range of total length $(\mathrm{mm})$ of killifish in each of the ponds studied

\begin{tabular}{|lcccc|}
\hline Pond & N & Mean & Median & Range \\
\hline F. bermudae & & & & \\
Blue Hole Bird Pond & 704 & 55.0 & 54.0 & $34-97$ \\
$\begin{array}{l}\text { Mangrove Lake } \\
\text { West Walsingham }\end{array}$ & 664 & 71.9 & 67.0 & $52-126$ \\
$\quad$ Ponds & 513 & 48.3 & 48.0 & $27-72$ \\
$\begin{array}{l}\text { Trott's Pond } \\
\text { Warwick Pond }\end{array}$ & 500 & 61.5 & 56.0 & $36-100$ \\
$\begin{array}{l}\text { F. relictus } \\
\text { Bartram's Pond }\end{array}$ & 150 & 77.1 & 79.5 & $41-129$ \\
Lover's Lake & 500 & 53.8 & 53.0 & $38-92$ \\
& 500 & 63.0 & 63.0 & $41-97$ \\
\hline
\end{tabular}

Table 4. Fundulus bermudae and F. relictus. Female to male sex ratios (F:M) of killifish in each of the ponds studied

\begin{tabular}{|lcc|}
\hline Pond & $\mathrm{N}$ & $\mathrm{F}: \mathrm{M}$ \\
\hline F. bermudae & & \\
Blue Hole Bird Pond & 704 & $1.78: 1$ \\
Mangrove Lake & 664 & $1.17: 1$ \\
West Walsingham Ponds & 513 & $1.86: 1$ \\
Trott's Pond & 500 & $1: 1$ \\
Warwick Pond & 150 & $1.21: 1$ \\
F. relictus & & \\
Bartram's Pond & 500 & $2.06: 1$ \\
Lover's Lake & 500 & $1.08: 1$ \\
\hline
\end{tabular}

Table 5. Fundulus bermudae and F. relictus. Summary of the statistical tests for male (M) and female (F) killifish size and sex ratio $(\mathrm{M}: \mathrm{F})$ comparisons in each pond. Differences were tested with Mood Median tests and chi-squared tests (with 1 degree of freedom), respectively. Significant differences between the sexes are in bold $(p<0.05)$

\begin{tabular}{|lcccc|}
\hline & N & F vs. M & \multicolumn{2}{c|}{ F:M } \\
& & size & \multicolumn{2}{c|}{ sex ratio } \\
& & $\mathrm{p}$ & $\chi^{2}$ & $\mathrm{p}$ \\
\hline F. bermudae & & & & \\
Blue Hole Bird Pond & 704 & 0.285 & 54.2 & $\mathbf{< 0 . 0 0 1}$ \\
Mangrove Lake & 664 & 0.062 & 3.46 & $>0.05$ \\
West Walsingham Ponds & 513 & $\mathbf{0 . 0 2 3}$ & 47.71 & $<\mathbf{0 . 0 0 1}$ \\
Trott's Pond & 500 & 0.325 & 0 & $>0.05$ \\
Warwick Pond & 150 & $\mathbf{0 . 0 0 9}$ & 1.31 & $>0.05$ \\
F. relictus & & & & \\
Bartram's Pond & 500 & 0.127 & 60.13 & $<\mathbf{0 . 0 0 1}$ \\
Lover's Lake & 500 & $\mathbf{0 . 0 0 6}$ & 0.8 & $>0.05$ \\
\hline
\end{tabular}

Evan's Pond. There were 4 other populations living in man-made ponds (created by dredging), where killifishes had been intentionally introduced as a precaution against possible extinction events. Fundulus relictus from Lover's Lake had been introduced in 1986 to
Bartram's Pond on the Stoke's Point nature reserve, and in 1995 F. bermudae from one of the West Walsingham Ponds had been introduced to Blue Hole Bird Pond in the Blue Hole Park. In 1976, specimens of F. bermudae from Trott's Pond had been introduced to an artificially created saltwater pond on the Nonsuch Island nature reserve, while specimens of the same species from Mangrove Lake were later introduced, after adaptation, to an artificial freshwater pond on the same island in 1993 (Table 1) (D. B. Wingate pers. comm.). By 2001, it was suggested that 2 of the naturally occurring Fundulus populations extant in the 1990s might have died out (Grady et al. 2001), and in 2003 at least one population on Nonsuch Island had disappeared as a result of total destruction of a saltwater pond during Hurricane Fabian (J. Madeiros pers. comm.)

The present survey results reconfirmed the presence of all the naturally occurring populations of Fundulus known to be extant in the 1990s, as well as 2 of the 4 translocated populations in the man-made ponds. Killifishes were not, however, found on the Nonsuch Island nature reserve, despite a recent (1993) introduction in one of the ponds. These results indicate that Bermuda's Fundulus species may have completely disappeared from the coastal mangrove and the inland marsh communities that may have provided a degree of continuity between isolated killifish pond populations. The extant populations were found living mostly in ponds of the eastern parishes of the islands, with 2 exceptions. Most of these ponds are small, isolated and anchialine in nature. Human modification of historical killifish habitats is clearly the single greatest reason why distribution is currently limited.

Site visits, direct observation and trapping proved to be effective in identifying extant populations; however, it remains possible that small killifish populations were overlooked in the present study. Other Fundulus species are well known for utilizing shallow water sediments for refuge (Minckley \& Klaassen 1969). It is feasible that a very small population dispersed around a fairly large area, and living almost exclusively in the bottom sediment would create the illusion that a pond was uninhabited. This may have been the case in Warwick Pond, thereby leading conservationists to believe (erroneously) that the original population had disappeared by 2001.

\section{Population and individual sizes}

Prior to this investigation little was known of the health and status of Bermuda's Fundulus populations. Knowledge of basic population estimates and their structure is necessary for conservationists to make 
informed management decisions and is critical to the development of species recovery plans.

The Petersen Index method for estimating population size in the present study gave consistent results. Malone et al. (1999) showed that VIE tagged fish were not vulnerable to higher levels of predation when compared with unmarked fish, and VIE tags have high retention rates when implanted in fishes (e.g. Dewey \& Zigler 1996, Frederick 1997). In addition, it was reasonable to assume that there was negligible recruitment or loss in the mark populations because of the geographic isolation of each pond and the short survey period (i.e. weekly samples for $4 \mathrm{wk}$ )

Trapping intensity varied between ponds, as did the time of year when each survey was performed, so it was not possible to compare the sizes or sex ratios of each Fundulus population amongst ponds to determine whether significant differences occurred. Previous studies investigating the size of individuals of F. heteroclitus populations from North Carolina, USA, and Nova Scotia, Canada, report maximum ranges from 90 to $120 \mathrm{~mm}$ total length (TL) (Fritz \& Garside 1975, Kneib 1976). In a comprehensive study of killifishes in a salt marsh in Tar Landing Bay (North Carolina), Kneib (1976) reported that the sizes of F. heteroclitus caught in minnow traps were in the range 16 to $72 \mathrm{~mm}$ standard length (SL) (approximately $90 \mathrm{~mm}$ TL), with an average size of $37.8 \mathrm{~mm}$ SL (or approximately $47.5 \mathrm{~mm}$ TL). Similarly Fernández-Delgado (1989) stated that the largest individuals sampled in a population introduced to the Guadalquivir marsh of southwest Spain were 100 to $120 \mathrm{~mm}$ TL, although larger fish measuring up to $132 \mathrm{~mm}$ TL were sporadically caught. In comparison, the populations of killifishes in Bermuda that were sampled with minnow traps during 2004 and 2005 ranged from 27 to $129 \mathrm{~mm}$ TL and the mean sizes ranged from 48.3 to $77.1 \mathrm{~mm}$ TL (Table 3). Only 2 individuals out of 3531 examined measured over 120 mm TL. Kneib (1976) used a combination of minnow traps and pit traps to collect fish of all age classes. Pit traps resembled small, water-filled depressions that occur on marsh mud surfaces at low tides. This trapping technique was most effective for fish of 5 to $40 \mathrm{~mm} \mathrm{SL}$, but was not usable in this study because Bermuda's ponds have a very limited tidal range (Thomas et al. 1991) and no exposed mud. Thus, the sample ranges and sample means (Table 3) are not fully representative of the entire population in each pond, leading to overestimation of the mean fish size of each pond population (as well as underestimation of population size). Kneib (1976) reported that young-ofthe-year killifishes in their first growing season (Age 0, $<30 \mathrm{~mm}$ SL) made up approximately $60 \%$ of the fish population in a month (August) represented by all age classes in Tar Landing Marsh. Fernández-Delgado
(1989) reported a similar finding in southwest Spain. It is likely therefore that the population estimates (Table 2) for Bermuda's killifishes are conservative.

Since Bermuda's killifish are now found in a few isolated populations, consideration has to be given to their viability in the short and long term. Population size is a major factor in the survival or extinction of populations: larger sizes provide insurance against unpredictable environmental events (environmental stochasticity) as well as stochastic changes in age structure, genetic drift and inbreeding depression (see Thompson 1991, Reed et al. 2003 for discussion). When considering the viability of vertebrate populations, there is a generally accepted 50/500 'rule of thumb' that a minimum of 50 adults is required to prevent an unacceptable level of inbreeding, and a population of 500 adults is required to maintain genetic variability (Franklin 1980, Soule 1980). If this is true, all of the Bermuda ponds currently containing killifish would appear to have sufficiently large populations, with the exception of Warwick Pond (estimated population size 436 individuals > 27 mm TL), and possibly Evan's Pond and the East Walsingham Ponds. Certainly, the killifishes would seem to be less threatened than the extensively studied desert pupfish Cyprinodon spp., some populations of which have consisted of $<500$ individuals for many decades (e.g. Chernoff 1985). However, more recent modeling exercises have taken stochastic events of demography and environment into consideration (see Reed et al. 2003), especially for fish (Nelson \& Soule 1987), and suggest that long-term survival (>40 generations) requires minimum populations of the order of 5000. Given this criterion, the killifish populations in Bartram's Pond and the West Walshingham Ponds would be counted among those more vulnerable to extinction - and this does not take into account the fact that it is not feasible in the field to distinguish between the 2 endemic Bermudian killifish species, so that the pond-species attributions shown in Table 1 are tentative rather than definitive. Environmental stochasticity, associated with the frequent hurricanes that affect Bermuda, may have a greater influence on the probability of species survival than genetic issues (though the data of Grady et al. (2001) indicate some genetic bottlenecks); however, in either case, a minimum population size of 5000 seems a sensible target for insuring the survival of these isolated populations.

\section{Sexual dimorphism, sex ratios, and predation}

As with Fundulus heteroclitus populations in previous studies (Kneib 1976, Fernández-Delgado 1989), Bermuda's Fundulus females appeared to grow larger 
than males. In all pond samples except Bartram's Pond, female median sizes were greater than males, though this difference was not always statistically significant (Table 5). Fernández-Delgado (1989) found that overall sex ratios in $F$. heteroclitus on the southwestern Iberian Peninsula did not differ significantly from 1:1, whereas the sex ratio data of the $F$. heteroclitus population in the Tar Landing Marsh study (Kneib 1976) showed a seasonal trend with a bias towards females in late winter, spring and early summer in the larger size classes. Females in Bermuda outnumbered males in all ponds surveyed, except Trott's Pond, where the sexes occurred in equal numbers. It is possible that males are less likely to enter a baited trap during the breeding months, and male territoriality might affect local sex ratios. However, this explanation seems improbable, since females consistently outnumbered males in the survey samples, some of which extended past the spring and summer breeding months (e.g. Blue Hole Pond, Mangrove Lake, Bartram's Pond, Trott's Pond and Warwick Pond).

Selective predation may explain the observed sex ratios in Bermuda's killifishes. Males are more conspicuous due to their brighter colouration during the spawning months, thus making them more likely to be targeted by predators. Observations (M. Outerbridge pers. obs.) suggest that Bermuda's killifishes are eaten by piscivorous birds and fishes that include resident and migratory herons belonging to the family Ardeidae, gray snappers Lutjanus griseus, the American eel Anguilla rostrata, and probably the mosquito fish Gambusia holbrooki. The last species preys on a wide variety of fish species globally, and its introduction has contributed to the demise of many populations of native fishes with similar ecological requirements to killifishes (Meffe 1985, Page \& Burr 1991). G. holbrooki was deliberately introduced to Bermuda in 1928 as a biological agent in mosquito control (Smith-Vaniz et al. 1999); it is prevalent in nearly all of Bermuda's inland wetland habitats, including 5 of the Fundulus ponds (Bartram's Pond, the East Walsingham Ponds, Trott's Pond, Mangrove Lake, and Warwick Pond). While eastern mosquito fish are not likely to be a threat to larger killifishes, they may be to eggs and fry. The combined effects of predation by this diverse suite of piscivorous birds and fishes on the Fundulus species of Bermuda are unknown at present.

\section{Environmental factors}

Fundulus species have been reported to withstand a wide range of temperatures and salinities (Griffith 1974, Kneib \& Stiven 1978). Waas \& Strawn (1983) found that the reproductive activity of $F$. grandis ceased during hot midsummer months in shallow water ponds and that fish living in deeper tide marsh environments had heavier gonads and carried more ripe eggs than the pond populations. While it appears that the Fundulus populations in Bermuda's ponds recruit, despite the shallow nature of many of them (Outerbridge 2006), the small population found in Warwick Pond, and low population numbers (anecdotal evidence) in both Evan's Pond and the East Walsingham Ponds, is a cause for concern. High summer water temperatures caused by extreme shallowness, particularly in both Warwick and Evan's Ponds that have mean depths of 20 and $65 \mathrm{~cm}$, respectively, together with low levels of dissolved oxygen (Thomas et al. 1991, M. E. Outerbridge \& M. L. H. Thomas unpubl. data), may affect gonadal maturation and egg survivorship. Greeley \& MacGregor (1983) suggested that constant high temperatures may slow the rate of ovarian rematuration in F. grandis sufficiently to limit the potential frequency of spawning, while Taylor \& DiMichele (1983) found that extended periods of immersion with oxygen levels lower than $2.0 \mathrm{ml} \mathrm{l}^{-1}$ resulted in developmental arrest or death of $F$. heteroclitus eggs. Both factors could cause a failure in recruitment that, operating repeatedly over a time span of a few years, could cause a crash in numbers as an ageing population dwindles. This may explain why the population structure in Warwick Pond was dominated by large individuals, where the median size was $79.5 \pm$ 16.5 (SD) mm TL (Outerbridge 2006).

\section{Taxonomy}

Subsequent to the colonization of Bermuda by the first founding population(s), isolating events, possibly in the form of sea level changes (Smith-Vaniz et al. 1999) followed by human induced habitat modification, have ensured that all extant Fundulus pond populations are now geographically and reproductively isolated from each other (Fig. 2). A possible exception may be the ponds in the Walsingham area - a tract of land with a network of ponds, subterranean caves and passages, most of which are flooded with seawater. As a result of the isolating events, genetic differentiation and speciation may have occurred within each population across Bermuda.

The taxonomic diversity of Bermuda's killifishes has still not been fully resolved, despite at least 2 efforts within the last 20 yr (Able \& Felley 1988, Grady et al. 2001). Smith-Vaniz et al. (1999) have proposed that there may be an additional 2 endemic species present. Clarification of the number and distribution of Bermuda's Fundulus taxa is necessary for the imple- 
mentation of management strategies. The latest taxonomic investigation of Bermuda's killifishes used sequence variation in the mitochondrial Cytochrome b gene from 4 extant populations (Grady et al. 2001). The results indicated that the populations did not appear to have accumulated intrapopulation variation or much interpopulation haplotype diversity', (p. 47); however, the authors suggested that 'more rapidly evolving genes...should be used to investigate both the taxonomic and conservation status of these populations', (p. 50). Consequently, new DNA analyses are currently being undertaken using fin clippings of all extant Fundulus populations.

\section{Management and recommendations}

Since the 1960s, local organizations including the Bermuda Audubon Society and the Bermuda National Trust have raised funds to purchase wetland habitats, holding them in trust as nature reserves, thus ensuring some protection against development. At the government level, protective planning legislation in 1983 designated all of the remaining wetland areas in Bermuda as nature reserves. Additional efforts have been made by a number of conservation agencies to raise public awareness regarding the ecological and aesthetic value of Bermuda's limited wetland habitats. Deliberate restoration projects have focused on the fresh and brackish marsh pond habitat, with the end result that a variety of ponds and marshes have been physically and biologically re-established island wide. The results of the present study provide crucial information that has informed the design of a killifish management and recovery plan, which is presently being drafted by the Bermuda government's Department of Conservation Services. Already it is evident that restoration of coastal wetland habitats, combined with transfer of killifishes from the larger extant pond populations, would be a sensible step forward - but should await more definitive genetic characterization of populations. The most immediate need is to evaluate the possibility of ameliorating the situation of killifishes living in small populations in very shallow ponds.

Acknowledgements. This is contribution \#115 of the Bermuda Biodiversity Project (BBP), Bermuda Aquarium, Natural History Museum and Zoo. This investigation was initiated by the BBP, and funding was provided by the Ernest E. Stempel Foundation, Mr. and Mrs. Anthony Jonklaas of the Kenridge Fund, and the Bermuda Government Department of Conservation Services. The support of these sponsors is gratefully appreciated. Thanks are due to Dr. Sarah Manuel and Anson Nash of the Department of Conservation Services Applied Ecology Unit and also to Evan Outerbridge for providing technical assistance in the field, as well as to Dr. Wolfgang Sterrer for his review of an earlier draft of the manuscript.

\section{LITERATURE CITED}

Able KW, Felley JD (1988) Bermuda Fundulus (Pisces: Fundulidae) revisited: taxonomy of the endemic forms. Proc Acad Nat Sci Phila 140:99-114

Able KW, Hata D (1984) Reproductive behavior in the Fundulus heteroclitus-F. grandis complex. Copeia 1984:820-825

Beebe W, Tee-Van J (1933) Field book of the shore fishes of Bermuda and the West Indies. GP Putnam's Sons, New York

Chernoff B (1985) Population dynamics of the Devils Hole pupfish. Environ Biol Fish 13:139-147

Dewey MR, Zigler SJ (1996) An evaluation of fluorescent elastomer for marking bluegill sunfish in experimental studies. Prog Fish-Cult 58:219-220

Fernández-Delgado, C (1989) Life history patterns of killifish Fundulus heteroclitus (L.) introduced in the estuary of the Guadalquivir River (southwest Spain). Estuar Coast Shelf Sci 29:573-582

Franklin IR (1980) Evolutionary change in small populations. In: Soule ME, Wilcox BA (eds) Conservation biology, an evolutionary-ecological perspective. Sinauer, Sunderland, MA, p 135-149

Frederick JL (1997) Evaluation of fluorescent elastomer injection as a method for marking small fish. Bull Mar Sci 61: 399-408

Fritz ES, Garside ET (1975) Comparison of age composition, growth and fecundity between two populations each of Fundulus heteroclitus and Fundulus diaphanous (Pisces, Cyprinodontidae). Can J Zool 53:361-369

Grady JM, Coykendall DK, Collette BB, Quattro JM (2001) Taxonomic diversity, origin, and conservation status of Bermuda killifishes (Fundulus) based on mitochondrial cytochrome b phylogenies. Conserv Genet 2:41-52

Greeley MS Jr, MacGregor R (1983) Annual and semilunar reproductive cycles of the gulf killifish, Fundulus grandis, on the Alabama gulf coast. Copeia 1983:711-718

Griffith RW (1974) Environmental and salinity tolerance in the genus Fundulus. Copeia 1974:319-331

Hurdis JL (1897) Rough notes and memoranda relating to the natural history of the Bermudas. RH Porter, London

Kneib RT (1976) Feeding, growth and movements of killifishes on a North Carolina salt marsh. Masters thesis, University of North Carolina, Chapel Hill, NC

Kneib RT, Craig AH (2001) Efficiency of minnow traps for sampling mummichogs in tidal marshes. Estuaries 24: 884-896

Kneib RT, Stiven AE (1978) Growth, reproduction and feeding of Fundulus heteroclitus (L.) on a North Carolina salt marsh. J Exp Mar Biol Ecol 31:121-140

Malone JC, Forrester GE, Steele MA (1999) Effects of subcutaneous microtags on the growth, survival and vulnerability to predation of small reef fishes. J Exp Mar Biol Ecol 237:243-253

Meffe GK (1985) Predation and species replacement in American southwestern fishes: a case study. Nature 30:173-187

Meredith WH, Lotrich VA (1979) Production dynamics of a tidal creek population of Fundulus heteroclitus (Linnaeus). Estuar Coast Mar Sci 8:99-118

Minckley CO, Klaassen HE (1969) Burying behavior of the plains killifish Fundulus kansae. Copeia 1969:200-201

Nelson K, Soule M (1987) Genetical conservation of exploited fishes. In: Ryman N, Utter F (eds) Population genetics and fishery management. Washington Sea Grant Program, Seattle, p 345-368

Outerbridge ME (2006) Distribution, population assessments and reproductive seasonality of Bermuda's killifishes. MSc thesis, University College Cork 
Outerbridge ME, Davenport J, Glasspool AF (2006) Ecology and conservation of Bermuda's endemic killifishes (Fundulus bermudae \& Fundulus relictus). Bermuda Biodiversity Project Special Publication 2006-002. Bermuda Zoological Society, Flatts Village

Outerbridge ME, Davenport J, Glasspool AF (2007) Reproductive seasonal periodicity of the Bermuda killifish Fundulus bermudae in an anchialine pond. J Mar Biol Assoc UK 87:797-800

Page LM, Burr BM (1991) Peterson's field guide to freshwater fishes. Houghton Mifflin Company, Boston, MA

Rand T (1981) Comparison of the parasite fauna and diets of two species of Bermuda mangrove fishes; Part II gut contents. In: Bermuda Department of Agriculture and Fisheries Monthly Bulletin. Bermuda Department of Agriculture, Hamilton, p 83-85

Reed DH, O'Grady JJ, Brook BW, Ballou JD, Frankham R (2003) Estimates of minimum viable population sizes for vertebrates and factors influencing these estimates. Biol Conserv 113:23-34

Ricker WE (1958) Handbook of computations for biological statistics of fish populations. Fish Res Board Can, Bulletin No. 119. Queen's Printer, Ottawa

Smith-Vaniz WF, Collette BB, Luckhurst BE (1999) Fishes of Bermuda: history, zoogeography, annotated checklist, and identification keys. Am Soc Ichthyol Herpetol, Spec Publ No. 4, Lawrence, KS

Soule ME (1980) Thresholds for survival: maintaining fitness and evolutionary potential. In: Soule ME, Wilcox BA (eds)

Editorial responsibility: Brendon Godley (Editor-in-Chief), University of Exeter, Cornwall Campus, UK
Conservation biology: an evolutionary-ecological perspective. Sinauer Associates, Sunderland, MA, p 151-169 Sterrer WE, Wingate DB (1981) Wetlands and marine environments. In: Hayward SJ, Gomez VH, Sterrer WE (eds) Bermuda's delicate balance. Bermuda Biological Station for Research, Spec. Publ. No. 20, Island Press, Hamilton, p 107-112

Sweeney J, Deegan L, Garritt R (1998) Population size and site fidelity of Fundulus heteroclitus in a macrotidal saltmarsh creek. Biol Bul 195:238-239

Taylor MH, DiMichele L (1983) Spawning site utilization in a Delaware population of Fundulus heteroclitus (Pisces: Cyprinodontidae). Copeia 1983:719-725

Thomas MLH, Logan A (1992) A guide to the ecology of shoreline and shallow-water marine communities of Bermuda. Bermuda Biological Station for Research, Spec. publ. No. 30, Wm. C. Brown Publishers, Dubuque, IA

Thomas MLH, Eakins KE, Logan A (1991) Physical characteristics of the anchialine ponds of Bermuda. Bull Mar Sci 48: 125-136

Thomas MLH, Eakins KE, Logan A, Mathers SM (1992) Biotic characteristics of the anchialine ponds of Bermuda. Bull Mar Sci 50:133-157

Thompson GG (1991) Determining minimum viable populations under the Endangered Species Act. US Department of Commerce, NOAA Tech Memo NMFS F/ NWC-198

Waas BP, Strawn K (1983) Seasonal and lunar cycles in gonadosomatic indices and spawning readiness of Fundulus grandis. Contrib Mar Sci 26:127-141

Submitted: April 10, 2007; Accepted: June 19, 2007 Proofs received from author(s): July 31, 2007 